\title{
To study the efficacy of Lavang, Ela, Sitopala, Sphatica churna pratisaran in danta sharkara
}

\section{Research article}

\author{
Sumedha J. Pundge $^{1^{*}}$, Yogesh T. Kotangale ${ }^{2}$ \\ 1. Assistant Professor, Department of Shalakyatantra, \\ 2. Associate Professor P.G. Department of Kayachikitsa, \\ CSMSS Ayurved College, Kanchanwadi, Aurangabad- 431002, Maharashtra, India.
}

\begin{abstract}
Due to rapid changes in living life style, diet, ignorance towards oral hygiene and the taboos about dental diseases are actually on increase. Out of these dental diseases danta sharkara has the most common occurrence. It is compared with modern disease i.e. dental tartar. No medical treatment is available in Modern Science for tartar, so it becomes essential to search a effective medical treatment. 'Lavang, ela, sitopala, sphatica' churna pratisaran used for the treatment of Dantasharkara. The property of churna is tridoshshamak, rasa, rakta, asthidhatu dushtihara \& lekhaniya. So the present study is aimed to evaluate the efficacy of above described churna pratisaran in Dantasharkara. It is found that therapy used in the experimental group is effective in reducing dantasharkara.
\end{abstract}

Key words: Churna, pratisaran, danta sharkara, dental tartar.

\section{Introduction:}

There is nothing most attractive than a beautiful smile, whether you are creating it or wearing. For a beautiful smile, oral health is of almost great importance by knowing its value WHO has declared October as "Oral Health Care Month". Good oral health requires good gums \& strong teeth.

Lack of dental care awareness is the prominent factor responsible for dental problems \& other factors are excessive consumption of bakery products, fast foods, chocolate, ice-creams, fermented food items, mixed diet, addictions like

\footnotetext{
*Corresponding Author:

Sumedha J. Pundge

CSMSS Ayurved College,

Kanchanwadi, Paithan road,

Aurangabad-431002 (Maharashtra)

Mobile: 9970820505

E-mail: sumedhayk@yahoo.com
}

chewing gutka, tobacco, betelnut, smoking, drinking tea, coffee, and alcohol. The prevalence rate of dental tartar is 9 out of 10 people in America \& tooth loss in $25 \%$. In Indian scenario it occurs $50 \%$ in children \& $90 \%$ in adults (1).

Dental tartar is one of the most hazardous conditions continuously increasing in the society $\&$ is the major cause of tooth loss in United States. In this disease plaque formation occurs which gets deposited by micro organisms \& saliva. This leads to calculus formation, pocket formation, gingivitis, alveolar bone loss, pyorrhea etc. In modern pharmacotherapy, the mainstay of treatment is prevention. It includes application of hexachlorhexidine, hexachlorophene and drugs as antiplaque agents. But these have side effects as tooth discolouration, oral irritation (2). Another is parasurgical treatment i.e. scaling which has side effects as enamel separation, irritation \& not affordable to poor patients. 
No medical treatment is available for Tartar in modern science.

Considering all these facts, it becomes necessary to look for an alternative Ayurvedic medical treatment which would be safe, cheap, easily available and curative for dantdsharkara. According to Yogratnakara Dantasharkara is having kaphavataj predominance \& rasa, rakta, asthi dhatu dushti .It has also mentioned various kriyakalpas e.g .swedan, vaman, virechan, kawal ,gandush, pratisaran for the treatment. Out of which kawal \& pratisaran are most important treatment modalities (3). Acharya Sadanand Sharma has mentioned a remedy for dantasharkara in Rasatarangini i.e. 'Lavang, Ela, Sitopala, Sphatica' churna pratisaran (4). It has tridoshshamaka, dhatudushtihara property due to which pacifies the dosha \& dhatudushti in danta sharkara.

\section{Aims and objectives:}

1) To study the role of 'Lavang, Ela, Sitopala, Sphatica' churna pratisaran in Dantasharkara w.r.t. Dental tartar.

2) To avoid complications of danatsharkara.

3) To prescribe comparatively cheap and easily available remedy for the patients.

\section{Methods and Materials:}

For the present study, 60 patients of danta sharkara were selected. These patients were randomly selected into 2 groups.

\section{Experimental Group:}

In this group all 30 patients will be given Lavang (cloves), Ela (cardamomum), Sitopala (Rock sugar), Sphatica churna (Potassium alum) pratisaran along with koshna jala kaval on danta Sharkara.

\section{Control Group:}

In this group all 30 patients will be treated with koshna jala kaval.

\section{Duration of Study:}

2 times per day for 1 month with weekly follow up. Special instructions about dietary habits, addictions \& oral hygiene were given to patient.

\section{Selection of patients:}

The patients who form the material of present clinical study will be selected from OPD and IPD of Shalakyatantra dept. of Govt. Ayurved College and Hospital, Nanded.

\section{Follow up:}

The patients will be observed for 1 month with weekly follow up. The follow up will be at $8^{\text {th }}$ day, $15^{\text {th }}$ day, $22^{\text {nd }}$ day, and $29^{\text {th }}$ day. Each patient will be reexamined thoroughly and clinical finding will be specially prepared for CRF. The patients can be examined with the help of source of light, tongue depressor, dental mirror \& dental probe.

\section{Selection criteria:}

1) The patients of either sex.

2) The patients above 10 and below 50 years of age.

3) The patients of danta sharkara having symptoms like red puffy gums, gums tenderness or pain, persistent bad breath, tooth discoloration, pus or spontaneous bleeding from gums.

4) The patients willing to take treatment.

\section{Exclusion criteria:}

1) The patients less than 10 and above 50 years were rejected.

2) The patients with gingivitis, pyorrhea, gingival abscess, and dental caries were excluded from the study. 
3) The patients with glossitis, stomatitis, pharyngitis, tonsillitis, oral sub mucus fibrosis were excluded.

4) Any malignant conditions of mouth, ear, nose, eye.

5) The patients with systemic diseases like DM, hypertension, tuberculosis, asthma were excluded.

6) The patients not willing for the treatment.

\section{Investigation:}

1) $\mathrm{Hb} \%$

2) Bleeding time

3) Clotting time

4) Blood sugar level

5) Urine examination for albumin examination.

\section{Parameters for observation}

1) Dental tartar

\begin{tabular}{|l|l|l|}
\hline Tartar absent & - & 0 \\
\hline Tartar seen upto gum margin & - & + \\
\hline
\end{tabular}

\begin{tabular}{|ll|l|l|}
\hline Supragingival and subgingival & - & ++ \\
\hline
\end{tabular} tartar outer side of teeth

Heavy Supragingival and $-{ }^{+++}$ subgingival tartar on inner \& outer side of teeth

\section{2) Foul smell}

\begin{tabular}{|l|l|l|}
\hline No foul smell & - & 0 \\
\hline Occasionally foul smell & - & + \\
\hline Continuous foul smell & - & ++ \\
\hline $\begin{array}{l}\text { Patient and doctor realize foul } \\
\text { smell }\end{array}$ & & +++ \\
\hline
\end{tabular}

Drug Preparation:

\begin{tabular}{|l|l|l|}
\hline Lavang & - & 1 part \\
\hline Ela & - & 1 part \\
\hline Sitopala & - & 1 part \\
\hline Sphatica churna & - & 1 part \\
\hline
\end{tabular}

Dose: 1-3 gm according to severity of the disease.

These drugs will be mixed in equal quantities properly and this churna will be locally applied on danta Sharkara. ${ }^{(5)}$

Table No.1, shows the experimental drugs and their properties.

\begin{tabular}{|l|l|l|l|l|l|l|l|}
\hline $\begin{array}{l}\text { Sr. } \\
\text { no }\end{array}$ & Dravya & Latin name & $\begin{array}{l}\text { English } \\
\text { Name }\end{array}$ & Rasa & Vipak & Virya & $\begin{array}{l}\text { Guna \& } \\
\text { doshkarma }\end{array}$ \\
\hline 1 & Lavang & $\begin{array}{l}\text { Syzygium } \\
\text { Aromaticum } \\
\text { (linn) (6) } \\
\text { Merr. \& Per. }\end{array}$ & Cloves & $\begin{array}{l}\text { Tikta, } \\
\text { katu }\end{array}$ & Katu & Sheet & $\begin{array}{l}\text { Laghu, tikta, } \\
\text { tikshna } \\
\text { Kapha- } \\
\text { pittahar }\end{array}$ \\
\hline 2 & Ela & $\begin{array}{l}\text { Elettaria } \\
\text { cardamomum } \\
\text { Maton(7) }\end{array}$ & Cardamomum & $\begin{array}{l}\text { Katu, } \\
\text { madhur }\end{array}$ & Madhur & Sheet & $\begin{array}{l}\text { Laghu, } \\
\text { snigha, } \\
\text { sukshma } \\
\text { Tridoshamak }\end{array}$ \\
\hline 3 & Sitopala & $\begin{array}{l}\text { Saccharum } \\
\text { officinarum } \\
\text { (linn) }\end{array}$ & Rock sugar & Madhur & Madhur & Sheet & $\begin{array}{l}\text { Guru, } \\
\text { snigdha } \\
\text { Vata-pittahar }\end{array}$ \\
\hline 4 & Sphatica & $\begin{array}{l}\text { Argilla } \\
\text { vitriolutum }\end{array}$ & $\begin{array}{l}\text { Pottasium } \\
\text { aluminium } \\
\text { sulphate }\end{array}$ & $\begin{array}{l}\text { Kashay, } \\
\text { amla, } \\
\text { katu }\end{array}$ & Katu & Sheet & \begin{tabular}{l} 
Tridoshamak \\
\hline
\end{tabular} \\
\hline
\end{tabular}

\section{Observation:}

The patients were examined thoroughly and the finding was recorded before and after completion of therapy. Tatar on teeth and foul smell of mouth are the most leading clinical 
determined the significance of improvement in symptoms. The level of significance was set as $5 \%, \mathrm{P}<0.05 \mathrm{t}_{\text {calculated }}>\mathrm{t}$ table indicates significance of finding.

Table No.2, shows the effect of treatment on tartar during each follow up and before $\&$ after treatment in experimental group.

\begin{tabular}{|l|l|c|c|c|c|c|}
\hline Sr.No. & Follow up (Days) & M.D. & S.D. & S.E. & T & P \\
\hline 1 & $1-8_{\text {th }}$ & 0.3333 & 0.4794 & 0.0875 & 3.8079 & $\mathrm{P}<0.05$ \\
\hline 2 & $8-15_{\text {th }}$ & 0.4333 & 0.5040 & 0.0920 & 4.7092 & $\mathrm{P}<0.05$ \\
\hline 3 & $15-22_{\text {nd }}$ & 0.3333 & 0.4794 & 0.0875 & 3.8079 & $\mathrm{P}<0.05$ \\
\hline 4 & $22-30_{\text {th }}$ & 0.5666 & 0.5040 & 0.0920 & 6.1582 & $\mathrm{P}<0.05$ \\
\hline $\mathbf{5}$ & BT-AT(mean) & $\mathbf{1 . 6 6 6}$ & $\mathbf{0 . 4 7 9 4}$ & $\mathbf{0 . 0 8 7 5}$ & $\mathbf{3 . 8 0 7 9}$ & $\mathbf{P}<\mathbf{0 . 0 5}$ \\
\hline
\end{tabular}

Abbreviations: M.D. (mean deviation), S.D. (standard deviation), S.E. (standard error), $T$ (T value), $P$ (P value).

The above table shows that $\mathrm{p}<0.05$. It means that $\mathrm{t}$ calculated $>t$ table. Thus the treatment is significantly effective in reducing the tartar.

Table No. 3 shows the effect of treatment on tartar in control group.

\begin{tabular}{|l|l|c|c|c|c|c|}
\hline Sr.No. & Follow up (Days) & M.D. & S.D. & S.E. & T & P \\
\hline 1 & $1-8_{\text {th }}$ & 0 & 0 & 0 & 0 & $\mathrm{P}>0.05$ \\
\hline 2 & $8-15_{\text {th }}$ & 0 & 0 & 0 & 0 & $\mathrm{P}>0.05$ \\
\hline 3 & $15-22_{\text {nd }}$ & 0 & 0 & 0 & 0 & $\mathrm{P}>0.05$ \\
\hline 4 & $22-30_{\text {th }}$ & 0 & 0 & 0 & 0 & $\mathrm{P}>0.05$ \\
\hline $\mathbf{5}$ & BT-AT(mean) & $\mathbf{0}$ & $\mathbf{0}$ & $\mathbf{0}$ & $\mathbf{0}$ & $\mathbf{P}>\mathbf{0 . 0 5}$ \\
\hline
\end{tabular}

The above table revels that there is no significant change in tartar BT \& AT and also each follow up.

Table No. 4, shows the comparison of effect of both treatments on tartar:

\begin{tabular}{|l|l|c|c|c|c|c|}
\hline Sr.No. & Follow up (Days) & M.D. & S.D. & S.E. & T & P \\
\hline 1 & $1-8_{\text {th }}$ & 0.3333 & 0.3390 & 0.08753 & 3.8078 & $\mathrm{P}<0.05$ \\
\hline 2 & $8-15_{\text {th }}$ & 0.4333 & 0.3563 & 0.0920 & 4.7091 & $\mathrm{P}<0.05$ \\
\hline 3 & $15-22_{\text {nd }}$ & 0.3333 & 0.3390 & 0.0875 & 3.8078 & $\mathrm{P}<0.05$ \\
\hline 4 & $22-30_{\text {th }}$ & 0.5666 & 0.3563 & 0.0920 & 6.1581 & $\mathrm{P}<0.05$ \\
\hline $\mathbf{5}$ & BT-AT(mean) & $\mathbf{1 . 6 6 6 7}$ & $\mathbf{0 . 3 3 9 0}$ & $\mathbf{0 . 0 8 7 5 3}$ & $\mathbf{1 9 . 0 3 9}$ & $\mathbf{P}<\mathbf{0 . 0 5}$ \\
\hline
\end{tabular}

The above table shows that $\mathrm{t}$ calculated $>\mathrm{t}$ table. Thus the treatment is significantly effective in reducing the tartar than control group.

Table No. 5, shows the effect of treatment on foul smell during each follow up and before $\&$ after treatment in experimental group:

\begin{tabular}{|l|l|c|c|c|c|c|}
\hline Sr.No. & Follow up (Days) & M.D. & S.D. & S.E. & T & P \\
\hline 1 & $1-8_{\text {th }}$ & 0.30 & 0.47 & 0.09 & 3.53 & $\mathrm{P}<0.05$ \\
\hline 2 & $8-15_{\text {th }}$ & 0.23 & 0.43 & 0.08 & 2.97 & $\mathrm{P}<0.05$ \\
\hline 3 & $15-22_{\text {nd }}$ & 0.30 & 0.47 & 0.09 & 3.53 & $\mathrm{P}<0.05$ \\
\hline 4 & $22-30_{\text {th }}$ & 0.80 & 0.41 & 0.07 & 10.77 & $\mathrm{P}<0.05$ \\
\hline $\mathbf{5}$ & BT and AT(mean) & $\mathbf{1 . 6 1}$ & $\mathbf{0 . 6 1}$ & $\mathbf{0 . 1 1}$ & $\mathbf{1 4 . 5 5}$ & $\mathbf{P}<\mathbf{0 . 0 5}$ \\
\hline
\end{tabular}


The above table revels that there is significant reduction in foul smell BT \& AT and also during each follow up.

Table No. 6, shows the effect of treatment on foul smell in control group:

\begin{tabular}{|l|l|c|c|c|c|c|}
\hline Sr.No. & Follow up (Days) & M.D. & S.D. & S.E. & T & P \\
\hline 1 & $1-8_{\text {th }}$ & 0 & 0 & 0 & 0 & $\mathrm{P}>0.05$ \\
\hline 2 & $8-15_{\text {th }}$ & 0.07 & 0.25 & 0.05 & 1.44 & $\mathrm{P}>0.05$ \\
\hline 3 & $15-22_{\text {nd }}$ & 0.07 & 0.25 & 0.04 & 1.49 & $\mathrm{P}>0.05$ \\
\hline 4 & $22-30_{\text {th }}$ & 0.23 & 0.50 & 0.09 & 2.54 & $\mathrm{P}>0.05$ \\
\hline $\mathbf{5}$ & BT and AT (mean) & $\mathbf{0 . 3 7}$ & $\mathbf{0 . 5 6}$ & $\mathbf{0 . 1 0}$ & $\mathbf{3 . 6 1}$ & $\mathbf{P}<\mathbf{0 . 0 5}$ \\
\hline
\end{tabular}

The above table reveals that there is no significant change in foul smell in first 3 follow up but after $22^{\text {nd }}$ day it shows significant reduction in foul smell.

Table No. 7, shows the comparison of effect of both treatments on foul smell:

\begin{tabular}{|l|l|c|c|c|c|c|}
\hline Sr.No. & Follow up (Days) & M.D. & S.D. & S.E. & T & P \\
\hline 1 & $1-8_{\text {th }}$ & 0.3 & 0.33 & 0.09 & 3.52 & $\mathrm{P}<0.05$ \\
\hline 2 & $8-15_{\text {th }}$ & 0.17 & 0.35 & 0.09 & 1.87 & $\mathrm{P}<0.05$ \\
\hline 3 & $15-22_{\text {nd }}$ & 0.23 & 0.38 & 0.10 & 2.40 & $\mathrm{P}<0.05$ \\
\hline 4 & $22-30_{\text {th }}$ & 0.57 & 0.46 & 0.12 & 4.79 & $\mathrm{P}<0.05$ \\
\hline $\mathbf{5}$ & BT and AT (mean) & $\mathbf{1 . 2 7}$ & $\mathbf{0 . 5 9}$ & $\mathbf{0 . 1 5}$ & $\mathbf{8 . 3 7}$ & $\mathbf{P}<\mathbf{0 . 0 5}$ \\
\hline
\end{tabular}

The above table revels that there is significant change between the effects of both treatment in reduction of foul smell. Thus treatment of study group is more effective than control group.

Table No. 8, shows the result of both groups on tartar and foul smell:

\begin{tabular}{|l|l|l|}
\hline Parameters & MD of Group I, BT \& AT & $\begin{array}{l}\text { MD of Group II, BT \& } \\
\text { AT) }\end{array}$ \\
\hline Dental tartar & 1.666 & 0 \\
\hline Foul smell & 1.61 & 0.37 \\
\hline
\end{tabular}

Following figure shows that, Lavang, ela, sitopala, sphatica' churna pratisaran results are highly significant in dental tartar and foul smell.

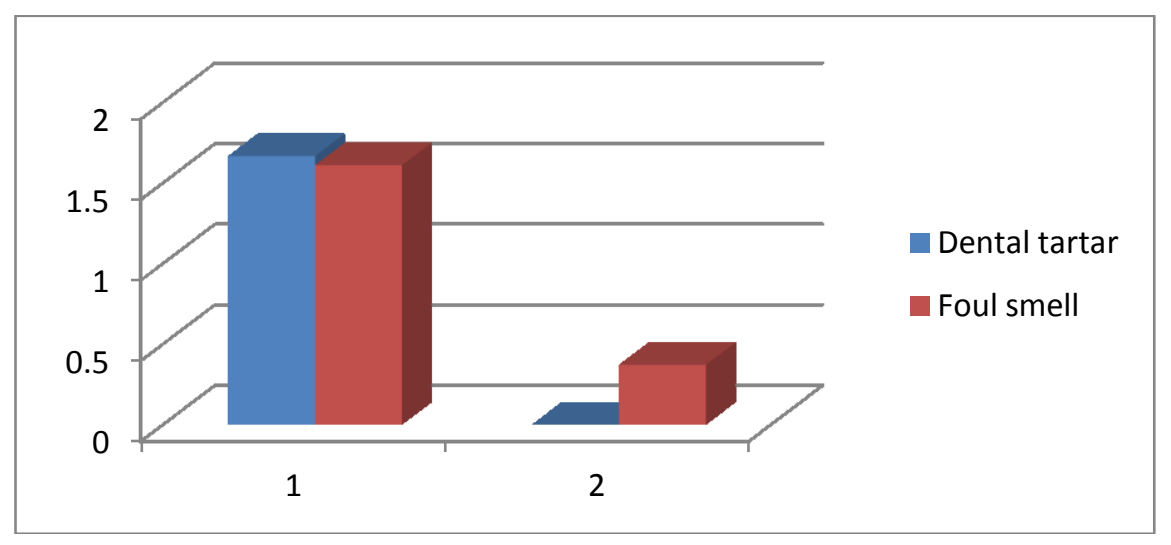




\section{Discussion:}

The prevalence of danta sharkara was found more in patients 20-30 years age group, most in males, students \& serviceman, having addictions of tobacco, gutkha, using mixed diet with excessive use of bakery products, fast food, chocolate, ice-cream those residing in urban area doing dantadhavana once daily \& with fingers \& patients of kaphavataj prakruti.

To analyze the results of both groups paired " $t$ " test was applied \& comparison of both groups was assessed by applying unpaired " $t$ " test at 5\% significant level. It shows that tartar \& foul smell of mouth is having highly significant results in experimental group \& only foul smell of mouth is having significant results in control group.

After complete assessment it was found that in experimental group $25(83.33 \%)$ patients were cured, $5(16.67 \%)$ patients were improved. In control group no patients were cured having tartar \& 5(16.67\%) patients were improved having foul smell. It was clear that patients with mild to moderate signs \& symptoms were cured and with moderate to severe symptoms were improved in experimental group. No any side effects were seen in any of patients.

\section{Conclusion:}

From the above study, it is concluded that therapy used in the experimental group is effective in reducing dantasharkara. It is proved to be cost effective, safe and easily available remedy in this disease and having no any side effects or any allergy. Thus for the treatment of dantasharkara this can be alternative treatment of choice which gives best relief from the symptoms like tartar and foul smell of mouth, only in I and II grade of tartar and all the three grades of foul smell. No complications were observed during the course of study.

\section{References:}

1. htpp://www.etymonline.com/index.php ?term $=$ tartar\&allowedinframe $=0$, 25Feb2011, 09.26am.

2. William G. Shafer, textbook of oral pathology, Aporism Indian Edition.

3. Yogratnakar with hindi commentary by Laxmipatishastri, Edited by Bhishgratna Bramhashankar Shastri, Edition, Chaukhamba Prakashan ,Varanasi, Uttartantra, Adhyaya-7,pp291 .

4. Rastarangini with hindi commentary by Sadananda Sharma, $11^{\text {th }}$ edition, edited by Kashinath Shastri Chaukhamba Sanskrit Sansthan,Varanasi pp. 205.

5. Priyavata Sharma, Dravyaguna vidnyan, Chaukhamba Bharati Academy, Varanasi, $16^{\text {th }}$ edition, 1995.

6. International union of pure \& applied chemistry (2005) Nomenclature of inorganic chemistry RSC-IUPAC electronic version.

7. Lewis, Charlton $\mathrm{T}$, short Charles, cardamomum, A Latin Dictionary. 


\section{PHOTOGRAPHS OF PATIENTS}

Before Treatment
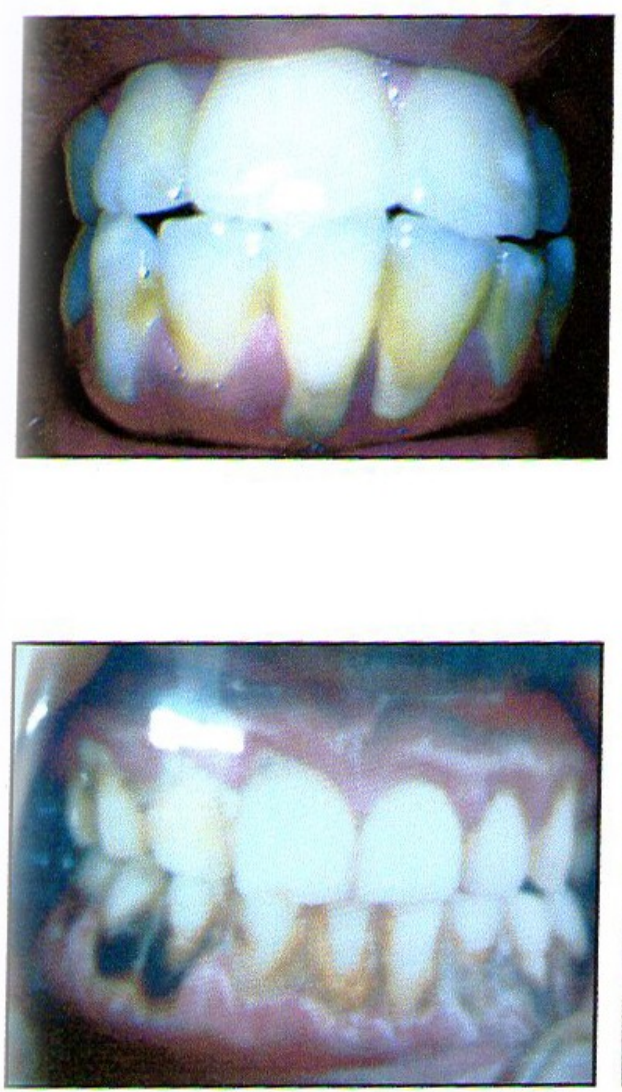

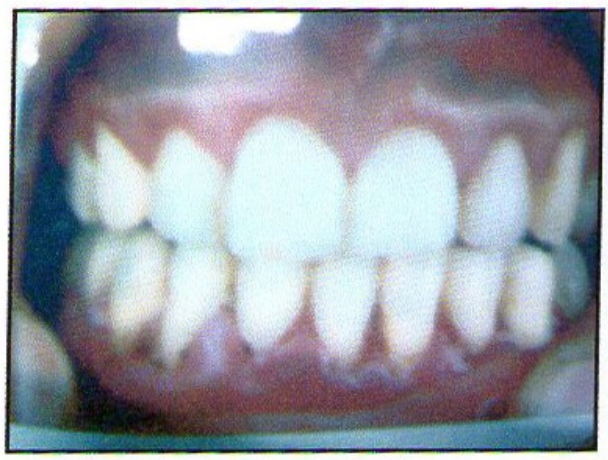

After Treatment
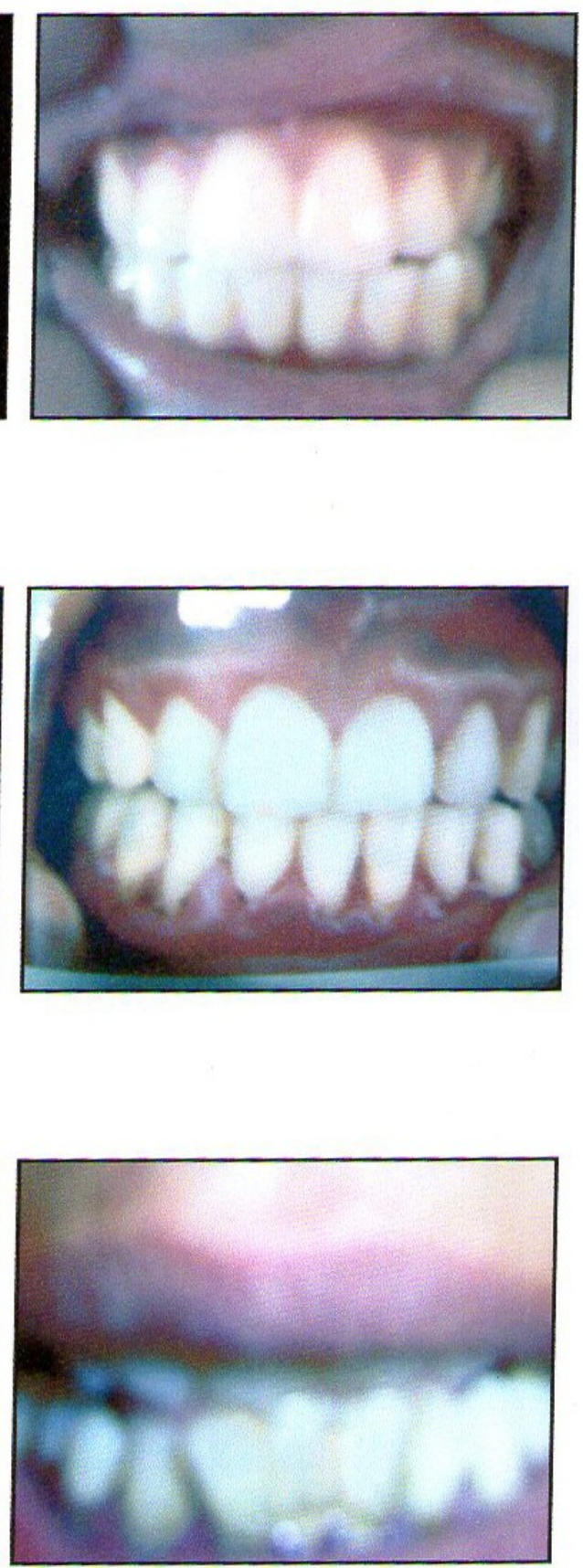